\title{
Complete atrioventricular block on isolated guinea pig heart induced by an aqueous fraction obtained from Psidium guajava L. leaf
}

\author{
Antonio N.S. Gondim ${ }^{1}$, Vanda R. Oliveira', Lusa R. Silva ${ }^{1}$, Bagnólia A. Silva², \\ Eduardo A. Conde-Garcia ${ }^{1 *}$
}

${ }^{1}$ Laboratório de Biofísica do Coração, Departamento de Fisiologia, Universidade Federal de Sergipe, Av. Marechal Rondon, s/n, 49100-000, Aracaju, SE, Brazil,

${ }^{2}$ Laboratório de Tecnologia Farmacêutica, Universidade Federal da Paraíba, Caixa Postal 5009, 58059-900, João

Pessoa, PB, Brazil

\begin{abstract}
RESUMO: "Bloqueio atrioventricular completo em coração isolado de cobaia produzido por uma fração aquosa obtida das folhas de Psidium guajava L.". O presente trabalho visou estudar o efeito eletrocardiográfico produzido pela fração aquosa (AqF) obtida do extrato acético das folhas de Psidium guajava L. em coração isolado de cobaia. Os traçados eletrocardiográficos foram obtidos em corações batendo espontaneamente ou então sob estimulação elétrica. Os corações foram montados em uma sistema de perfusão do tipo Langendoff de fluxo constante. A AqF, usada em concentrações menores que $20 \mu \mathrm{g} / \mathrm{mL}$, não alterou a freqüência espontânea do coração (controle: $180 \pm 9 \mathrm{bpm}$, teste: $182 \pm 10 \mathrm{bpm} ; \mathrm{N}=3 ; \mathrm{p}>0,05)$. Todavia, concentrações iguais ou maiores que $20 \mu \mathrm{g} / \mathrm{mL}$ produziram bloqueio atrioventricular completo (BAV). Este efeito, contudo, desapareceu prontamente quando se removeu a $\mathrm{AqF}$ do fluido de perfusão coronariana ( $\mathrm{N}=3$ corações). $\mathrm{O}$ BAV promovido pela $\mathrm{AqF}$ se faz mediado pelos receptores muscarínicos porque o sulfato de atropina $(1,5 \mu \mathrm{M})$ impediu o aparecimento deste efeito.
\end{abstract}

Unitermos: Psidium guajava, coração isolado, electrocardiograma, bloqueio atrioventricular.

\begin{abstract}
This paper aimed to study the electrocardiographic effect produced by the aqueous fraction $(\mathrm{AqF})$ obtained from the acetic extract of Psidium guajava $\mathrm{L}$. leaf on the isolated guinea pig heart. Electrocardiographic records (ECG) were obtained on isolated hearts beating spontaneously or under regular electrical stimulation. The hearts were mounted in a constant flow Langendorff perfusion system. Until $20 \mu \mathrm{g} / \mathrm{mL}, \mathrm{AqF}$ did not change the spontaneous cardiac rate (control: 180 \pm 9 bpm, test: $182 \pm 10 \mathrm{bpm} ; \mathrm{N}=3 ; \mathrm{p}>0.05$ ). Concentrations equal or greater then $20 \mu \mathrm{g} / \mathrm{mL}$ induced complete atrioventricular block (AVB). However, this effect promptly disappeared when $\mathrm{AqF}$ was removed from the perfusion fluid ( $\mathrm{N}=3$ hearts). The AVB induced by AqF involves heart muscarinic receptors because atropine sulfate $(1.5 \mu \mathrm{M})$ could prevent the appearance of such disturbance.
\end{abstract}

Keywords: Psidium guajava, isolated heart, electrocardiogram, atrioventricular block.

\section{INTRODUCTION}

Psidium guajava L. is a plant commonly used by folk medicine. Despite that its effect on the mammalian heart remained unknown. Conde-Garcia et al. (2003) reported that some extracts obtained from $P$. guajava leaf depress the myocardial contractility. To test if the extract are also able to interfere with the electrophysiological properties of the myocardium this work was designed. P. guajava ("goiabeira" in Brazil) is originated from tropical America and its teas and infusions, prepared from leaves, have been used for treating intestinal colics, diarhea, cough, gingivitis, arterial hypertension and some intestinal parasites (Coee; Anderson, 1996; Ramirez et al., 1988; Pereira et al., 2004; Vendruscolo et al., 2005; Tôrres et al., 2005). Several biological effects have been reported to be associated to that plant. Among them it could be mentioned: depressor of motion activity (Luterodt; Maleque, 1988), depressor of central nervous system (Olajide; Awe; Makinde, 1999), inhibitor of retrovirus reversal transcriptase (Suthienkui et al., 1993), antimutagenic (Grover; Bala, 2000; Matsuo et al., 1994), antimalaric (Gessler et al., 1994), citotoxic (Arisawa, 1994), hypoglycemic (Cheng; Yang, 1983; Hsu; Cheng, 1992; Roman-Ramos; Flores-Saenz; Alarcon-Aguilar, 1995), antipyretic (Hussan; Nasralla; Chaudhuri, 1995), anti-inflammatory (Hussan; Nasralla; Chaudhuri, 1995; Tona et al., 1999), antibacterial and antifungal (CuellarCuellar; Arteaga Lara; Perez Zayas, 1984; Le Grand, 1989; Pessini et al., 2003; Alves et al., 2006), amebicide (Tona et al., 1999), giardicide (Ponce-Macotela et al., 1994), antialergic (Kossuge et al., 2000), myocardial protector (Yamashiro et al., 2003), anti-oxidant (Qian; Nihorimbere, 2004), and inhibitor of the enzyme

ISSN 0102-695X 
acetylcholinesterase (Barbosa-Filho et al., 2006).

In spite of its biological activities, the scientific literature is scarce concerned to its effect on the mammalian myocardium. Conde-Garcia et al. (2003) showed that the leaf acetic extract is able to reduce the atrial contractile force in a concentration-dependent fashion. To better understand the properties of $P$. guajava extracts on mammalian heart, the present work aimed to study the electrocardiographic effects produced on the guinea pig heart by the aqueous fraction of the acetic extract.

\section{MATERIAL AND METHODS}

\section{Botanical material}

P. guajava leaves were collected in Aracaju (Sergipe, Brazil) during January 2004 (summer time). A plant voucher was identified by Myrna Landim and deposited (Deposit number 008076) in the Herbarium (ASE 03304) of the Federal University of Sergipe (Aracaju, Sergipe, Brazil).

\section{Aqueous fraction preparation}

After being collected from healthy and agrotoxicfree plants, $P$. guajava leaves were carefully washed and dried $\left(50 \pm 2{ }^{\circ} \mathrm{C}, 10\right.$ days). $100 \mathrm{~g}$ of dry leaves were submitted to extraction in a Soxhlet apparatus by using the following solvents: hexane, chloroform, acetone, ethanol, and acetic acid. The acetic acid extract was evaporated (Rotary evaporator, TE-210, TECNAL, Brazil) and concentrated. After that it was stored at $-20{ }^{\circ} \mathrm{C}$ (Freezer FRICON - VCV -1C PVR, Brazil). AqF stands for the water-soluble fraction of the acetic extract.

\section{Animals}

Experiments were carried out on male adult $(300-500 \mathrm{~g})$ guinea pig (Cavia porcellus) heart. Animal handling followed recommendations of the Brazilian College for Animal Experimentation (COBEA).

\section{Substances}

Hexane (SYNTH, São Paulo, Brazil), chloroform
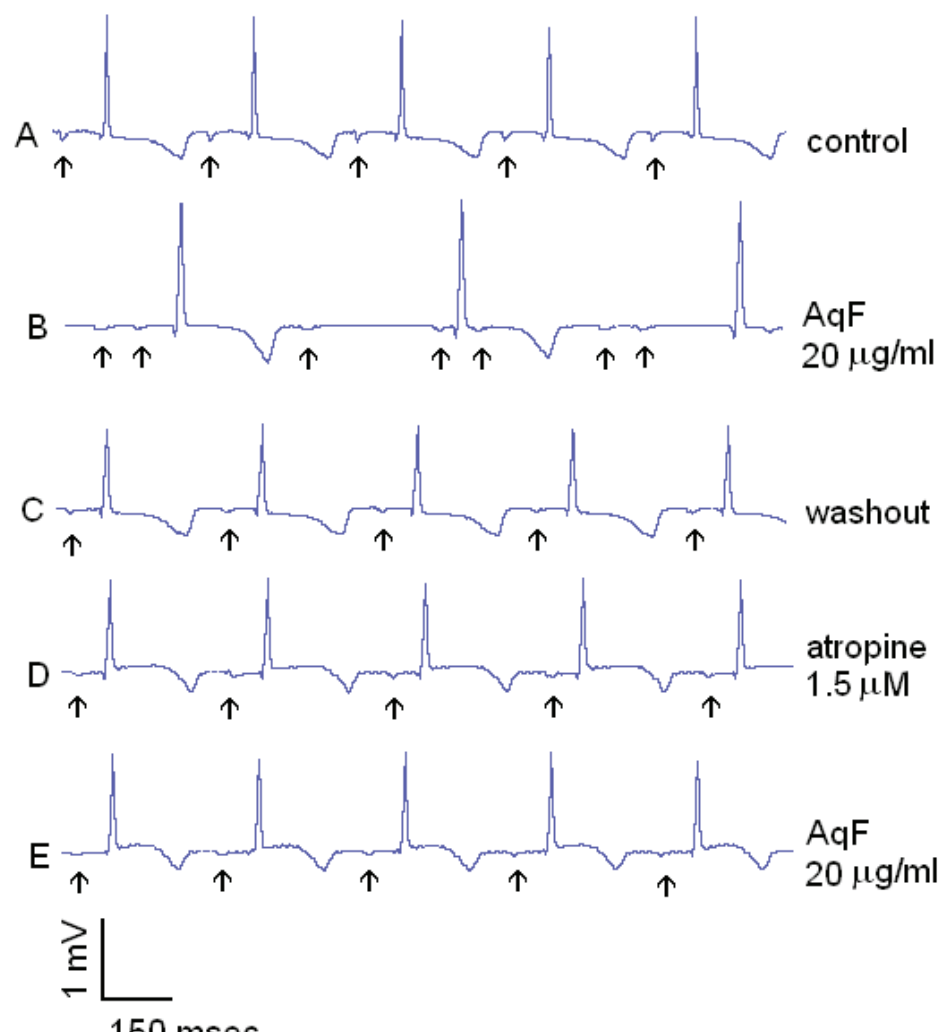

Figure 1. AqF effect on the ECG obtained from isolated guinea pig heart beating spontaneously. A: Control (Tyrode perfusion); B: 3rd degree atrioventricular block and atrial bigeminism produced by $20 \mu \mathrm{g} / \mathrm{mL}$ AqF added to the perfusion solution; $\mathbf{C}$ : $\mathrm{AqF}$ washout showing the disappearance of previous effects; $\mathbf{D}$ : ECG record obtained after adding atropine sulfate $(1.5 \mu \mathrm{M})$ to the perfusion fluid; $\mathbf{E}$ : ECG record obtained after the heart atropinization showing that atropine is able to prevent atrioventricular blockade. Arrowheads mark P wave occurrence $\left(34 \pm 0.1{ }^{\circ} \mathrm{C}\right)$. 
(Grupo Química, São Paulo, Brazil), potassium chloride, glucose, and sodium bicarbonate were purchased from MERCK (MERCK SA Indústrias Químicas, São Paulo, Brazil); acetone P.A., ethanol P.A., methanol P.A., glacial acetic acid, magnesium chloride, and monobase sodium phosphate were purchased from VETEC (VETEC Química Fina, São Paulo, Brazil). Sodium chloride was acquired from QUIMIS (São Paulo, Brazil), heparine (LIQUEMINE, ROCHE, Rio de Janeiro/Brazil), and atropine sulfate from SIGMA-ALDRICH (St.Louis, Mi, USA).

\section{Experimental setup for ECG recording}

Animals previously heparinized $(7,7 \mu \mathrm{g} / \mathrm{g}$ of body weight) were sacrificed by a blow applied to the skull base. Their hearts were rapidly removed, mounted in a constant flow Langendorff system $(5 \mathrm{~mL} / \mathrm{min}$, peristaltic pump MILAN, Equipamentos Científicos LTDA, Brazil), and perused by a modified Tyrode solution (Dorigo, $1990)$, which was oxigenated with carbogen mixture (5\% $\mathrm{CO}_{2}+95 \% \mathrm{O}_{2}$ ), and maintained at $34 \pm 0.1{ }^{\circ} \mathrm{C}$ (HAAKE F1, Germany). To avoid coronary microembolism, the perfusion fluid was carefully filtered in cellulose triacetate membranes (mesh $0.45 \mu \mathrm{m}$, SCHLEICHER \& SCHÜLL, Germany). The heart was electrically stimulated (DIGITIMER DS2, England) through a pair of stainless steel electrodes placed at the right atrial appendage. Stimulation rate (ANAPULSE STIMULATOR 302-T, USA and DIGITIMER DS2, England) was adjusted to be $20 \%$ higher then the spontaneous pacemaker rate. Heart electrical signals were captured by three electrodes $(\mathrm{Ag} /$ $\mathrm{AgCl} / \mathrm{NaCl} 1 \mathrm{M}$ ) placed inside the Tyrode in which the heart was maintained immersed. The ECG signals were monitored on a cardioscope screen (EMAI RX10, Brazil) and, after being amplified (HP ECG AMPLIFIER 8811B, HP7754A, USA), they were digitized at $512 \mathrm{~Hz} /$ channel (DI-205, DATAQ INSTRUMENTS, USA) and recorded in a computer.

\section{Electrocardiographic parameters}

To evaluate the AqF effect on the ECG, electrocardiographic records were obtained on control solution and after adding $20 \mu \mathrm{g} / \mathrm{mL} \mathrm{AqF}$ to that fluid. The chronotropic effect was evaluated in spontaneously beating hearts, whereas the effect of $\mathrm{AqF}$ on the conduction through the atrioventricular node was analyzed on both preparations hearts spontaneously and hearts electrically stimulated with ground-isolated rectangular pulses of current applied to the right appendage.

\section{Statistical analysis}

To decide about differences between means, the t-Student test for independent data was used. The significance level was $p<0.05$. In this paper the data are referred as mean \pm standard deviation.

\section{RESULTS}

$20 \mu \mathrm{g} / \mathrm{mL}$ of $\mathrm{AqF}$ induced a complete atrioventricular block in all of the hearts assayed. In spite of the strong effect, the cardiac rate did not changed (control: $180 \pm 9$ bpm; test: $182 \pm 10$ bpm; $\mathrm{N}=3$; $\mathrm{p}>$ $0.05)$. Figure 1 shows five ECG records obtained from isolated guinea pig hearts. During control (panel A) the spontaneous heart rate was $197 \mathrm{bpm}$ but when $\mathrm{AqF}(20 \mu \mathrm{g} / \mathrm{mL})$ was added to the perfusion solution an atrioventricular dissociation occurred (panel B). Furthermore, $\mathrm{AqF}$ induced atrial bigeminism, which is characterized by coupled extrasystoles. In the present example the interval of extrasystolic coupling was equal to $84 \mathrm{~ms}$. The electrocardiographic parameters recovers its control value after removing the $\mathrm{AqF}$ from the perfusion solution (panel C). To test if the atrioventricular blockade was dependent on the cholinergic receptors, atropine sulfate $(1.5 \mu \mathrm{M})$ was added to the perfusion solution. After five minutes from atropine perfusion, $\mathrm{AqF}$ was added to the perfusion fluid. This promoted a small increase of the spontaneous heart rate from $180 \mathrm{bpm}$ (panel D) to 189 bpm (panel E). Nevertheless, neither atrioventricular block nor extrasystoles could be recorded. Such behavior was seen in other two hearts.

\section{DISCUSSION}

After Conde-Garcia et al. (2003) reported that the crude extract from $P$. guajava leaf reduced the atrial contraction force, we decided to investigate if $\mathrm{AqF}$ also could act on the electrophysiological mechanisms of the mammalian heart. In underdeveloped countries, teas and infusions, prepared from P. guajava leaves, are used to control intestinal colics. This supported the present effort to better understand the electrophysiological depressant effects promoted by $P$. guajava extracts on the cardiac functioning. We found that the AqF could even block the electrical conduction through the AV node in isolated and perfused guinea pig hearts. The experiments were carried out in isolated guinea pig heart beating spontaneously or under electrical stimulation. AqF promoted a complete atrioventricular block leading to an atrioventricular dissociation rhythm. This effect involves the membrane muscarinic receptors because atropine sulfate, a nonselective muscarinic antagonist, was able to abolish it. The atrioventricular node is the most critical structure for the electrical impulse propagation from the atria to the ventricles. Through it the electrical wave spreads with a very slow speed, that is about 10 times lower then the atrial or ventricular one (Hoffman; Cranefield, 1960; Paes de Carvalho; Almeida, 1960). Such low speed is in part due to the small amplitude of its action potentials generated by the nodal cells, which are essentially composed by the slow component. This component is 
produced by slow calcium and sodium inward currents, as well as by the reduction of membrane conductance to the potassium ions. Therefore, drugs that lead to the inward calcium current reduction (e.g. verapamil) and/ or to the increase of membrane potassium conductance (e.g. acethylcholine) could promote impairment to the electrical propagation through the atrioventricular node. Activation of muscarinic receptors type $\mathrm{M}_{2}$ opens the inward potassium rectifier channels (acetylcholinesensitive potassium channels). Thus, when atrial, nodal, or Purkinje cells are exposed to muscarinic agonists, the cellular membrane resting potential increases (hyperpolarization) and the cellular action potential shortens (Krapvinsky et al., 1995). Another event that is associated to the muscarinic receptors activation on the myocardium concerns to the reduction of the L-type inward calcium current (Dhein; Van Koppen; Brodde, 2001). As AqF seems to act by activating cardiac muscarinic receptors then these electrophysiological events work to make the nodal action potential smaller in amplitude and, for that reason, they can explain both the atrioventricular block and the atrioventricular dissociation that could be found in the guinea pig heart perfused by $\mathrm{AqF}$. The contribution of nodal muscarinic receptors to the AqF-induced atrioventricular block seems to be of paramount importance.

\section{ACKNOWLEDGEMENTS}

ELETROBRÁS - Centrais Elétricas Brasileiras (Process Number 23113.009351/03-67) FAP-SE, FUNTEC FNS-MS - Fundação de Apoio à Pesquisa do Estado de Sergipe, Fundo Nacional de Saúde do Ministério da Saúde, Brasília/DF, Brazil (Process Number 01/2003) CNPq -Brazilian Research Council, Ministério da Ciência e Tecnologia, Federal Government, Brasília/ DF, Brazil.

\section{REFERENCES}

Alves PM, Leite PHAS, Pereira JV, Pereira LF, Pereira MSV, Higino JS, Lima EO 2006. Atividade antifúngica do extrato de Psidium guajava Linn. (goiabeira) sobre leveduras do gênero Candida da cavidade oral: uma avaliação in vitro. Rev Bras Farmacogn 16: 192196.

Arisawa M 1994. Cell growth inhibition of KB cells by plant extracts. Natural Med 48: 338-347.

Barbosa-Filho JM, Medeiros KCP, Diniz MFFM, Batista LM, Athayde-Filho PF, Silva MS, Cunha EVL, Almeida JRGS, Quintans-Júnior LJ 2006. Natural products inhibitors of the enzyme acetylcholinesterase. Rev Bras Farmacogn 16: 258-285

Cheng JT, Yang RS 1983. Hypoglycemic effect of guava juice in mice and human subjects. Am J Chin Med 11: 74-76.

Coee FG, Anderson GJ 1996. Ethnobotany of the garifuna of Eastern Nicaragua. Econ Bot 50: 71-107.

Conde-Garcia EA, Nascimento VT, Santiago-Santos AB 2003.
Inotropic effects of extracts of Psidium guajava $\mathrm{L}$. (guava) leaves on the guinea pig atrium. Braz J Med Biol Res 36: 661-668.

Cuellar-Cuellar A, Arteaga Lara R, Perez Zayas J 1984. Psidium guajava L. Phytochemical screening and study of the essential oil. Rev Cubana Farm 18: 661-668.

Dhein S, Van Koppen CJ, Brodde OE 2001. Muscarinic receptors in the mammalian heart. Pharmacol Res 34: $161-181$

Dorigo P, Gaion RM, Bergamin M, Giacometti A, Valentini E, Maragno I 1990. Comparison between the cardiac effects induced by muzolimine and furosemide in guinea-pig atria. Cardiovasc Drugs Ther 4: 14771486.

Gessler MC, Nkunyak MHH, Mwasumbi LB, Heinrich M, Tanner M 1994. Screening Tanzanian medicinal plants for antimalarial activity. Acta Tropica 56: 65-77.

Grover IS, Bala S 2000. Studies on antimutagenic effects of guava (Psidium guajava) in Salmonella typhimurium. Mutat Res 300: 1-3.

Hoffman BF, Cranefield PF 1960. The electrophysiology of the heart. New York: McGraw-Hill.

Hsu FL, Cheng JT 1992. Investigation in rats of the antihyperglycaemic effect of plant extracts used in Taiwan for treatment of diabetes mellitus. Phytother Res 6: 108-111.

Hussan TS, Nasralla SH, Chaudhuri AKN 1995. Studies on the antiinflammatory and related pharmacological activities of Psidium guajava: A preliminary report. Phytother Res 9: 118-122.

Kossuge T, Shishikura H, Kitanaka S, Toyoshima S 2000. Effects of Psidium components on cytokine productions in helper T cells and type-I allergy. Yakugaku Zasshi 120: 408-412.

Krapvinsky G, Krapvinsky L, Wickman K, Clapham DE 1995. $\mathrm{G} \beta \gamma$ binds directly to the $\mathrm{G}$ protein-gated $\mathrm{K}^{+}$channel $\mathrm{IK}_{\text {Ach }}$.J Biol Chem 270: 29059-29062

Le Grand A 1989. Anti-infectious phytotherapy of the treesavannah, (Western Africa) III: A review of the phytochemical substances and anti-microbial activity of 43 species. $J$ Ethnopharmacol 25: 315 338.

Lut erodt GD, Maleque A 1988. Effects on mice locomotor activity of a narcotic-like principle from Psidium guajava leaves. J Ethnopharmacol 24: 219-231.

Matsuo T, Hanamure N, Shimoi K, Nakamura Y, Tomita I 1994. Identification of $(+)$-galoocatechin as a bioantimutagenic compound in Psidium guajava leaves. Phytochemistry 36: 1027-1029.

Olajide OA, Awe SO, Makinde JM 1999. Pharmacological studies on the leaf of Psidium guajava. Fitoterapia 70: 25-31.

Paes de Carvalho A, Almeida DF 1960. Spread of activity through the atrioventricular node. Circ Res 8: 801809.

Pereira RC, Oliveira MTR, Lemos GCS 2004. Plantas utilizadas como medicinais no município de Campos de Goytacazes - RJ. Rev Bras Farmacogn 14(Supl. 1): 37-40.

Pessini GL, Holetz FB, Sanches NR, Cortez DAG, Dias-Filho BP, Nakamura CV 2003. Avaliação da atividade antibacteriana e antifúngica de extratos de plantas 
utilizados na medicina popular. Rev Bras Farmacogn 13(Supl. 1): 21-24.

Ponce-Macotela M, Navaro-Alegria I, Martinez-Gordillo MN, Alvarz-Chacon R 1994. In vitro effect against Giardia of 14 plant extracts. Rev Invest Clin 46: 343-347.

Qian H, Nihorimbere V 2004. Antioxidant power of phytochemicals from Psidium guajava leaf. $J$ Zhejiang Univ Sci 5: 676-683.

Ramirez VR, Mostacero LJ, Garcia AE, Mejia CF, Pelaez PF, Medina CD, Miranda CH 1988. Vegetales empleados en medicina tradicional norperuana. Trujillo: Banco Agrario del Peru \& Nacl. Univ.

Roman-Ramos R, Flores-Saenz JL, Alarcon-Aguilar FJ 1995. Anti-hyperglycemic effect of some edible plants. $J$ Ethnopharmacol 48: 25-32.

Suthienkui O, Miyazaki O, Chularisi M, Kositanont U, Oishi, K 1993. Retroviral reverse transcriptase inhibitory activity in Thai herbs and spices: screenning with moloney murine leukemia viral enzyme. Southeats Asian J Trop Med Public Health 24: 751-755.

Tona L, Kambu K, Mesia K, Cimanga K, Apers S, De Bruyne T, Pieters L, Totte J, Vlietinck AJ 1999. Biological screening of traditional preparations from some medicinal plants used as antidiarrhoeal in Kinshasa, Congo. Phytomedicine 6: 59-66.

Tôrres AR, Oliveira RAG, Diniz MFFM, Araújo EC 2005. Estudo sobre o uso de plantas medicinais em crianças hospitalizadas da cidade de João Pessoa: riscos e benefícios. Rev Bras Farmacogn 15: 373380.

Vendruscolo GS, Rates SMK, Mentz LA 2005. Dados químicos e farmacológicos sobre as plantas utilizadas como medicinais pela comunidade do bairro Ponta Grossa, Porto Alegre, Rio Grande do Sul. Rev Bras Farmacogn 15: 361-372.

Yamashiro S, Noguchi K, Matsuzaki T, Miyagi K, Nakasone J, Sakanashi M, Sakanashi M, Kukita I, Aniya Y, Sakanashi M 2003. Cardioprotective effects of extracts from Psidium guajava and Limonium wrightii, Okinawan medicinal plants, against ischemia-reperfusion injury in perfused rat hearts. Pharmacology 67: 128-135. 